\title{
Socio-Economic Importance of Honey among Traditional Healers and Orthodox Practitioners in Iwo Local Government Area of Osun State, Nigeria
}

\author{
${ }^{1}$ AYENI, OD; *2 ${ }^{2}$ DEKOLA, PJ; ${ }^{2}$ ADEREMI, AM; ${ }^{2}$ MAJEKODUNMI, O.A; \\ ${ }^{1}$ OKUMODI, BO; ${ }^{2}$ OLUWALANA, T
}

\author{
${ }^{I}$ Forestry Research Institute of Nigeria, Jericho, Ibadan. Oyo State, Nigeria \\ ${ }^{*}$ Federal College of Forestry, Ibadan, Oyo State, Nigeria \\ *Corresponding Author Email: Ayeniolatunji62@yahoo.com; adepop333@yahoo.co.uk; Tel: 08036673441,07081375931
}

\begin{abstract}
The necessity for people's adequate and quality as well as good health and standard of living for overall National development informed the main reason for the study on Socio-economic importance of honey among traditional healers and orthodox medical practitioners in Iwo Local Government Area, Osun State. A total of 105questionnaires wereadministered, while 91 were retrieved from the respondents. Various uses of honey were investigated both for personal consumption and medicinal purpose. The result shows that $41.8 \%$ of the respondent use honey for multiple purpose, while $35.2 \%$ use honey mainly for medicinal purpose, $16.5 \%$ use it mainly as beverages, while the remaining $6.6 \%$ for use in treatments. The Chi Square Test showed a higher calculated value of 385.71 than the tabulated value of 21.026. This confirms a strong relationship between the use of honey and social life of Iwo people. The major constraints discovered was that Traditional healers do not exercise strict control on the quantity doses of honey used for different ailments. It is therefore recommended that both rural and urban dwellers should be sensitized about the use of honey, in order to encourage sustainable consumption for improvement of health status.
\end{abstract}

\section{DOI: https://dx.doi.org/10.4314/jasem.v24i11.1}

Copyright: Copyright $($ C) 2020 Ayeni et al. This is an open access article distributed under the Creative Commons Attribution License (CCL), which permits unrestricted use, distribution, and reproduction in any medium, provided the original work is properly cited.

Dates: Received: 15 September 2020; Revised: 22 October 2020; Accepted: 30 October 2020

Keywords: Medicinal, orthodox, traditional, honey

Bee keeping is a forest and wildlife resources activity which helps in food production and income generation. This practice is environmentally friendly and closely link with other human activities (Ojatin et al 2003). Honey bees are very essential for the welfare of mankind not only because it provides man with honey but more importantly because honey bees ensure the fertility of many economic tree species that man depends upon for his direct and indirect food supply. Honey is the product of the digestion of nectar flowers by the worker bees. It has been a source of sweetness in the diet of human being and other animals from time immemorial. It is a food which is easily absorbed by the body system and can also restore oxygen rapidly to fatigue muscles. Honey also has antiseptics, antibiotics and anti-mitotic characteristics (Arowosegbe and Ajewole, 2005). The FAO codex Ailment Commission defines honey as the natural sweet substance produced by honey bees from the nectar of flowers or from secretion coming from the living organisms feeding on plants that bees gather, transformed and combined with specific ingredients, stored and leave to ripen in the combs of hive. Honey production from bee keeping is of considerable importance in the economy of both the developed and developing countries. It gives a profitable and healthy form of livelihood to a large number of people (Adekola et al., 2007). Honey is the most important bee product both from the quantitative and economic point of view, it is highly nutritious and medicinal food, especially in areas where sugar cannot be produced and medical facilities are not available. The major component of honey are sugars, which include fructose, sucrose, maltose, and other di- and trisaccharide sugars, it also contain a whole varieties of chemical components such as proteins, fats, vitamins, minerals, enzymes, amino acids, volatile aromatic substance, etc. Honey is used in the management of infection, according to Spencer (1993), he published a series of paper on the antimicrobial and wound healing effects of honey. He first published a series of 59 patients with wound and non-healing Ulcers, $80 \%$ of which had failed to heal with conventional therapy for period of one to two years. He showed that wound which initially cultured positive for a variety of organisms were sterile for a week and that 58 of the wounds went on to heal rapidly with separation of eschardimminihed edema and rapidly repitheliation. His method was to apply15-30 $\mathrm{ml}$ of unprocessed honey to the wound daily, after 
cleaning the wound with normal saline. Honey occupies an honored place in the minds of men and sacred status, in the Ancient world in many communities, it also has religious significance and is needed for almost all spiritual and rites of passage (Josh, 1990). In Hinduism, it is considered as one of the five components of the panchamrit, the nectar of immortality and are used in many religious ceremonies. Honey is also used as nourishing healthy food in varied forms and said to facilitate better physical performance. It provides as much as 3$5 \mathrm{~kg} / \mathrm{Cal} / \mathrm{kg}$ of energy which requires slight digestive action. Honey can be consumed directly or used in cakes, pastries, candies, chewing gum or with coffee. In many Himalayan regions, where sugar is not readily available, honey is used as substitute to sugar. It is also used as an energy food in preparing special dishes like pancake, salad and so on. These dishes are prepared for social ceremonies such as wedding and rice feeding ceremony for babies. The objective of this paper is to investigate the socio-economic importance of honey among traditional healers and orthodox practitioners in Iwo Local Government Area of Osun State, Nigeria

\section{MATERIALS AND METHODS}

The study Area: The study was carried out in Iwo Local Government, Osun State, Nigeria. Iwo, Osun, Nigeria is located at Nigeria country in the cities place category with GPS coordinates of $7^{\circ} 37^{\prime \prime} 45.1524^{\prime \prime} \mathrm{N}$ and $4^{\circ} 11^{\prime} 13.9848^{\prime \prime}$ E. Iwo experiences extreme seasonal variation in monthly rainfall. The rainy period of the year lasts for 9.5 months, from February 7 to November 23, with a sliding 31- day rainfall of at least 0.5 inches. The most rain falls during the 31 days centered on September13, with an average total accumulation of 9.2 inches. The rainless periods of the year lasts for 2-5 months, from November 23 to February 7. The least rain falls around January 3, with an average total accumulation of 1.2 inches. Iwo has an average temperature of $28.5^{\circ} \mathrm{C}$ and relative humidity of $65 \%$. The natural vegetation is the tropical Rain Forest which could be found in patches all over the district but mainly on hills.

Data collection: Field survey, which entails detailed appraisal of the uses of honey, were carried out through the use of structured questionnaires containing both open and close ended questions and opinion/target group discussions to gather relevant data from traditional healers and orthodox medical practitioners in Iwo Local Government Area, Osun State, Nigeria

Population and Sample: Primary data needed for the study were collected through multistage random sampling among the traditional healers and orthodox medical practitioner sratified. Fifteen percent $(15 \%)$ of the two sectors of healers were identified. Out of 400 traditional healers and 300 orthodox medical practitioners, 105 respondents were randomly selected for enumeration using structured questionnaires.

Data Analysis: The primary data collected was processed into suitable format for various analyses. Data analysis involved non-parametric tests using appropriate statistical tools. The following statistical analyses were carried out: The data were analyzed using descriptive statistics and Chi-square $\left(\chi^{2}\right)$ at 0.01 level of significance. Constraints identified include: Cough, Insomnia, Ulcer, Diarrhea, Constipation, Sore, Jaundice, Rashes, Asthma, Hemorrhage and Catarrh.

Descriptive Statistics: This involved frequency analysis, percentages, cross tabulations and bar graphs to depict trends in the use of honey in Iwo local Government, Osun State, Nigeria.

$$
\begin{aligned}
& \text { Chi-square }\left(X^{2}\right) \text { Test } \\
& \qquad X^{2}=\frac{\sum(O F-E F)}{E F}
\end{aligned}
$$

Where $\Sigma=$ Summation; OF $=$ Observed frequency, $\mathrm{EF}=$ Expected frequency

For tabulated value

$$
(\mathrm{nr}-1)(\mathrm{nc}-1) \mu \%
$$

Where $\mathrm{nr}=$ number of rows; $\mathrm{nc}=$ number of columns; $\mu=$ degree of freedom in percentage

\section{RESULTS AND DISCUSSION}

The table shows that the largest percentage of the honey users fell within the age of 41-50years (42.9\%). This implies that youths are less familiar with the importance of honey than the adult and moreover the youths preferred white collar jobs than strenuous business like honey production. Gender distribution shows that $72.5 \%$ were males while female made up the remaining $27.5 \%$ of the sample size. $83.5 \%$ are married, while educational background reveals that $91.5 \%$ of the respondents have tertiary education. $60.4 \%$ of the respondents are orthodox medical practitioners, their involvement is not unconnected to improvement in science and technology. The table 1 shows the various uses of honey. The multipurpose use of honey takes the largest percentage $(41.8 \%)$, while other uses share the remaining percentage. This implies honey has the quality of being put to various uses. 
Table 1 Socio - demographic characteristics of respondents

\begin{tabular}{lll}
\hline Variable & Frequency & Percentage \\
\hline Age & & \\
$21-30$ & 10 & 11.0 \\
$31-40$ & 29 & 31.9 \\
$41-50$ & 39 & 42.9 \\
$>50$ & 13 & 14.2 \\
Total & 91 & 100 \\
Gender & & \\
Male & 66 & 72.5 \\
Female & 25 & 27.5 \\
Marital status & & \\
Single & 1 & 1.1 \\
Married & 76 & 83.5 \\
Widowed & 12 & 13.5 \\
Divorced & 1 & 2.2 \\
Total & 91 & 100 \\
Educational background & \\
Primary & 1 & 1.1 \\
Secondary & 8 & 8.8 \\
Tertiary & 82 & 90.1 \\
Total & 91 & 100 \\
Occupation & & \\
Orthodox Healers & 55 & 60.4 \\
Traditional & 36 & 39.6 \\
Healers/farmers & & \\
Total & 91 & 100 \\
\hline
\end{tabular}

Table 2: Uses of honey

\begin{tabular}{lll}
\hline Uses & Frequency & Percentage (\%) \\
\hline Medicine & 32 & 35.2 \\
Beverage & 15 & 16.5 \\
Treatment & 6 & 6.6 \\
Multipurpose & 38 & 41.8 \\
Total & 91 & 100
\end{tabular}

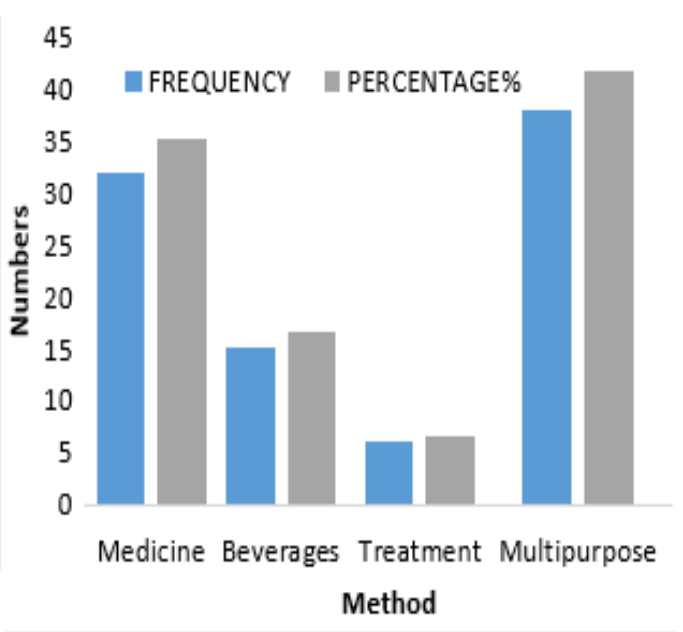

Fig 1. The various use of honey

Figure 1 above shows the frequency/percentages of different uses of honey. It can be deduced that out of the uses method multipurpose had the highest percentage, followed by honey used for medicinal purpose. Beverages use takes the third position and honey use for treatment of ailments was the last. This invariably shows the unawareness of people in the area of treating sickness and diseases.

The table 3 shows that there are a lot of medicinal use of honey. The respondents' testimonies were that honey in combination to other ingredients cures jaundice, cough, insomnia, etc. Figure 2 shows the various ailment that honey is been used for.

\begin{tabular}{|c|c|c|c|}
\hline Ailment & Frequency & $\%$ & Usage/treatment \\
\hline Cough & 8 & 8.8 & Mix and grind alligator pepper with honey and lick \\
\hline Insomnia & 1 & 1.1 & $\begin{array}{l}2-3 \text { tables spoonful of honey should be taken in the } \\
\text { morning. This should be repeated an hour before } \\
\text { going to bed, in order to relax the muscles }\end{array}$ \\
\hline Ulcer & 3 & 3.3 & $\begin{array}{l}2 \text { table spoonful of honey in warm water before each } \\
\text { meal }\end{array}$ \\
\hline Diarrhea & 1 & 1.1 & $\begin{array}{l}\text { Mix a small spoonful of garlic powder, with a cup of } \\
\text { tomato juice, half cup of honey and a pinch of salt. }\end{array}$ \\
\hline Constipation & 2 & 2.2 & $\begin{array}{l}\text { Mix honey and cow milk in a cup and drink it, after } \\
\text { swallowing one piece of garlic, rvery morning for five } \\
\text { days. }\end{array}$ \\
\hline Sore & 3 & 3.3 & $\begin{array}{l}\text { Regular application of honey, by robbing on affected } \\
\text { portions }\end{array}$ \\
\hline Jaundice & 1 & 1.1 & $\begin{array}{l}\text { Take a table spoon of honey before going to bed. } \\
\text { It tranquilizes nerves and heals Jaundice, because it } \\
\text { contains some tranquilizing elements like }\end{array}$ \\
\hline Rashes & 1 & 1.1 & Mix honey with black soap and camwood (osun) \\
\hline Asthma & 3 & 3.3 & Mix white liquid from snail with honey \\
\hline Haemorrhage & 1 & 1.1 & 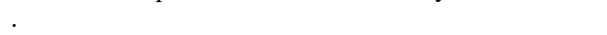 \\
\hline Catarrh & 1 & 1.1 & $\begin{array}{l}\text { Mixture of lime and honey at ratio } 1: 5 \text {. Take two } \\
\text { spoonful thrice in a day for five days }\end{array}$ \\
\hline $\begin{array}{l}\text { Multiple } \\
\text { response }\end{array}$ & 56 & 61.5 & \\
\hline Free users & 10 & 10.98 & Honey with hot or warm liquid \\
\hline Total & 91 & 100 & \\
\hline
\end{tabular}




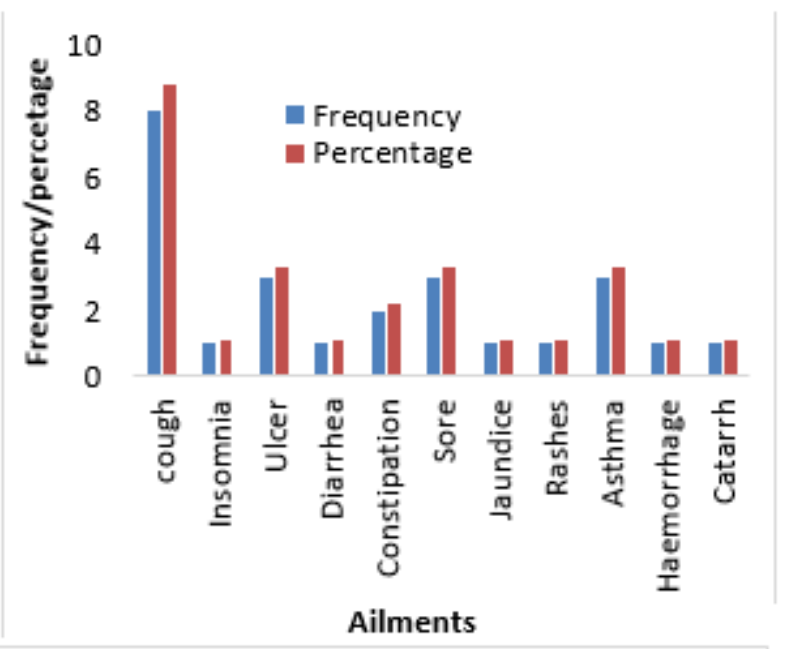

Fig 2 Medical uses of honey

\begin{tabular}{|c|c|c|c|c|}
\hline Variable & $\begin{array}{l}\text { Observed } \\
\text { frequency }(\mathrm{OF})\end{array}$ & $\begin{array}{l}\text { Expected } \\
\text { frequency }(\mathrm{EF})\end{array}$ & Residual & $(\mathrm{OF}-\mathrm{EF})^{2}$ \\
\hline Cough & 8 & 7.0 & 1.0 & 0.14 \\
\hline Insomnia & 1 & 7.0 & 6.0 & 5.14 \\
\hline Ulcer & 3 & 7.0 & 4.0 & 2.29 \\
\hline Diarrhea & 1 & 7.0 & 6.0 & 5.14 \\
\hline Constipation & 2 & 7.0 & 5.0 & 3.57 \\
\hline Sore & 2 & 7.0 & 4.0 & 2.29 \\
\hline Jaundice & 1 & 7.0 & 6.0 & 5.14 \\
\hline Rashes & 1 & 7.0 & 6.0 & 5.14 \\
\hline Asthma & 3 & 7.0 & 4.0 & 2.29 \\
\hline Haemorrhage & 1 & 7.0 & 6.0 & 5.14 \\
\hline Catarrh & 1 & 7.0 & 6.0 & 5.14 \\
\hline Multiple response & 56 & 7.0 & 49.0 & 343.0 \\
\hline Free users & 10 & 7.0 & 3.0 & 1.29 \\
\hline Total & 91 & & & \\
\hline
\end{tabular}

Figure 2 above show in the area of treatment of specified ailments, which one takes the largest percentage. Observation shows that people use hone most in the treatment of cough, followed by Ulcer, Sore and Ashtma that shared the same percentage. Those area where honey has not been used intensively should be encouraged.

The Chi square $\left(\mathrm{X}^{2}\right)$ value is $=315.71$. Note* significant at $5 \%$ level of significant. The result shows that there is significant relationship between the use of honey and social life of Iwo dwellers, since F Cal is greater than F Tab. From the result, the calculated value is 385.71 while the tabulated value is 21.026 . This implies that, honey does not only cure a single disease but it can cure various diseases as shown from the multiple response.

Conclusion: The study shows that honey plays important role in the socio-economic and the general health of the people in Iwo. The study shows the area where honey is less optimized that should be encouraged. This will boost the health status of the populace, more productivity and more income and increase standard of living. Hence, it is recommended to use honey for treatments of ailments aside from other uses as observed in the study.

\section{REFERENCES}

Adekola, PJ; Ojo, MO; Samuel, AA; Aruwayo, A; Aderounmu, AF (2006). Apiculture in Nigeria: A viable source of livelihood. J. Forest. Res. Manage. 3: 59-69

Arowosegbe, OB; Ajewole, IO (2005). The potential of bee keeping for sustainable Agroforestry in Nigeria. Proceedings of the $30^{\text {th }}$ Annual Conference of the Forestry Association of Nigeria, held in Kaduna State, Nigeria 07-11 November, 2005.

Adekola, PJ; Omoyajowo, AO; Ojo, MO; Fagbenro, JA (2007). Towards health and wealth generation through life science in honey production for sustainable development in Nigeria. A paper presented at the $5^{\text {th }}$ Conference of Nigeria Society 
Socio-Economic Importance of Honey among Traditional Healers.....

for experimental Biology (NISBB), $28^{\text {th }}$ of February - $3^{\text {rd }}$ of March 2007, Kogi State University, Anyigba, Kogi State, Nigeria p.48

Crane, E (1980). A book of honey, Oxford University press, U K, 193p

Dustman, J. H (1993) Honey quality and its control. America BEE J. $648-651$
Joshi, SR (1999). Physical Forestry Association of Nigeria held in Calabar, Cross - River State, Nigeria $6^{\text {th }}-11^{\text {th }}$ October 2003 , p.40-47

Spencer, EE (1993). University of Calabar, Nigeria. Published paper on the antimicrobial and wound healing effects of honey. 